e- migrinter

e-Migrinter

$20 \mid 2020$

Hospitalité et migration

\title{
Chibanis and chibanias or long-term (in)hospitality
}

A comparison between France and Morocco

Julie Leblanc and Jordan Pinel

\section{(2) OpenEdition}

Journals

Electronic version

URL: https://journals.openedition.org/e-migrinter/2574

DOI: 10.4000 /e-migrinter.2574

ISSN: 1961-9685

\section{Publisher}

UMR 7301 - Migrinter

Electronic reference

Julie Leblanc and Jordan Pinel, "Chibanis and chibanias or long-term (in)hospitality", e-Migrinter [Online], 20 | 2020, Online since 30 March 2021, connection on 20 May 2021. URL: http://

journals.openedition.org/e-migrinter/2574 ; DOI: https://doi.org/10.4000/e-migrinter.2574

This text was automatically generated on 20 May 2021.

Tous droits réservés 


\title{
Chibanis and chibanias or long-term (in)hospitality
}

\author{
A comparison between France and Morocco
}

Julie Leblanc and Jordan Pinel

1 The contemporary migratory context in Europe is best summarized by the word "crisis": "migrant crisis", "humanitarian crisis", "reception crisis", "hospitality crisis". The very term by definition refers to a sudden, sharp, unexpected phenomenon. This is why a so-called "migration crisis" cropped up in France in media and political discourse. However, it is by no means new. It so turns out that both of us have focused, in our research work, on earlier migratory experiences, namely those of women and men who are now in their sixties, who left Algeria and Morocco to come to France in the 1950s and 1960s, alone or with their families. What is common to the narratives of the people we interviewed is the precariousness and vulnerability experienced when they arrived in France, which for some is still part of their everyday life today. All of them have experienced shantytowns, hovels, insalubrious digs, makeshift accommodation with a relative, hunger, cold, the absence or violation of their rights, police checks and fear. Such precariousness, linked to the inhospitality of the institutional reception of immigrants in France, is epitomized by the "encamping of the world" (Agier, 2011). The "shantytown phenomenon" is "almost consubstantial with the migratory fact itself and (...) is therefore nothing new" (Chavanon, Leblanc, 2018). Thus, it is with this historical perspective in mind that we discuss in this article the concept of (in)hospitality and its implications in the daily lives of today's elderly immigrants. In an age of globalisation, we are faced with the spread and multiplication of border situations - whether physical, legal, or social. Beyond the quaintness of the term "hospitality", we understand it to be used here, following F. Brugère and G. Le Blanc, as a "journey" from "helping" to "welcoming" and ultimately to "belonging". These authors argue that the various stages and concrete actions of hospitality are by rights to be identified in infra-politics and a "hospitality counter-policy" (Brugère, Le Blanc, 2017). Faced with inhospitable states, emerging individual and collective initiatives are taken into account here. 
2 The data presented in this paper come from our respective PhD work in anthropology and geography, proposing a dual disciplinary approach to the issue of ageing populations originating from the Maghreb (Algeria and Morocco). On the basis of our field surveys conducted between 2013 and 2019 in France (Lyons, Marseilles) ${ }^{1}$ and in Morocco (Agadir, Tiznit) ${ }^{2}$, we address different social and territorial anchoring points. The more global picture we thus obtain, between France and Morocco, helps to better identify the challenges faced by ageing migrant populations, whether in the host society or in the country of origin. The discussion that has built up around these issues has also enabled gender-related observations to emerge, with strictly women-oriented or conversely essentially men-oriented fields. This complementary approach makes it possible to gain a better understanding of the experiences of institutional (in)hospitality and reactions to it, particularly from the point of view of associations and citizens. Thus, our purpose is not to show the experiences of these men and women as if they were solely overwhelmed by an inhospitable context which crushes them, but also to describe the agency at work for and by the people concerned here.

\section{(In)hospitality practices: living conditions and social rights of elderly migrants}

3 For migrant populations who arrived in France between the 1950s and 1970s, ageing and transition to retirement have raised questions about where to grow old. As the final imaginary destination of the migratory journey, the return home often becomes a "myth" in view of the extension of the stay in the host region and the gradual putting down of roots (Sayad, 1999). While some migrants settle permanently in the host country, others keep commuting between the two shores, making them physically present in the host society while remaining present in the processes taking place in their society of origin. Many of these "in-between" individuals have forged multiple identities throughout their migration experiences (Schaeffer, 2001). Many become "transmigrants" who "take several annual trips to the country of origin or at least one annual trip of more than one month" (Attias-Donfut, Gallou, 2006: 275-276). However, these stays in France are often seen as "a reversal of the classic perspective of immigration, 'disappearing' as an immigrant by returning to the country to invest in it or 'disappearing' as an émigré by integrating into the host society" (Daum, 2007, p. 167). By demonstrating the invisibility of women, compared to men, in these migratory movements associated with the migrant workers of the 1960s and 1970s, several studies have highlighted the essential role of women in migration from the Maghreb (Ait Ben Lmadani, 2012; El Hariri, 2003; Moujoud, 2010, Paiva, 2012). The gender approach has brought elements of understanding of old age immigration, highlighting the role of women in the decision not to return to the country of origin for good, particularly in their relations with children living in France:

"For a majority of women, the possession of a house [in the country of origin] or the retirement of a spouse remain insufficient reasons for deciding on a permanent return" (El Hariri, 2003, p. 47).

For these migrants, who more often than not arrived as sources of labour, it was by no means self-evident that retirement should be a synonym for "idleness" (Sayad, 2001). Working remained the only way to avoid being pigeonholed as a "useless migrant" by the host society (Arab, 2013). This unthought, and sometimes unthinkable, retirement 
accounts for the lack of visibility of this population in public policies. Indeed, public policies are not geared towards sustainable settlement and the practice of hospitality. In this sense, these people, who are viewed as being "destined to leave as soon as they arrive", find themselves, once retired, faced with legal and social problems, which are not very audible, particularly due to the lack of electoral stakes they represent. An activist association met in Agadir explains that "the Chibanis are a silent population because they cannot vote in the society where they live. They are therefore put aside". (Agadir, October 2017).

\section{From administration to housing: inhospitality in everyday life}

5 A number of studies have analysed the social rooting processes of immigrants in France, showing how they influence the decision not to return to the country of origin once they reach retirement. For example, frequent widowhood among the interviewees (especially among women), the number of years they had been in France, the links they had, or did not have, with their country of origin, their social origins and personal backgrounds at the time of emigration, their socio-professional background in France, the presence of a family environment or lack of it, their economic and social situation and that of their children, their health, the local and national context, particularly from the point of view of public policy or legislation, all clearly interfere with their decisions (Attias-Donfut, Gallou, 2006).

6 Furthermore, some pensioners, especially single men, are also forced into immobility by administrative procedures that prevent their return. ${ }^{3}$ Although the retirement pension can be paid abroad, various social benefits such as the Allocation de solidarité aux personnes âgées (old-age benefit) cannot. Beneficiaries must therefore stay in France for at least 180 days a year. In addition, the conditions for claiming health-related benefits are also subject to residency requirements in France. This general context is hardly an incentive for people to "return" and contributes to the precariousness of these pensioners if they nonetheless choose to live their retirement in their country of origin. A Moroccan association ${ }^{4}$ located in Agadir thus helps elderly migrants wishing to return with their legal and administrative procedures. During an interview, the president of the association explained the situation as follows:

"People who have worked in France for years and years, a whole generation, who have been working down the mines for example, in the coal industry. And they spent years and years there, and today they have illnesses, like the pensioner who is about to arrive. This man has a coal disease, with the dust and all that in his lungs after all the years he spent breathing in the coal. And there are many people like him. They spent 30 or 35 years working in the mines. And then they come back here and they get treated here... without any insurance! So he's the one who pays for all the medicine. He pays 130,000 dirhams ${ }^{5}$ a year for his anthrax treatment." (Agadir, November 2017).

7 The story of this pensioner, who found himself forced to pay for his medicine, is emblematic of the situation faced by many immigrant workers in France who have chosen to return home. In order to benefit from the French social security to which they contribute, they must reside in France for at least six months a year. Many pensioners therefore choice choose to remain forever "in-between", either because they wish to continue to receive social assistance or to continue to benefit from social 
security. So they draw up their schedules for visits to their home country around the "six months in France" constraint. They have to do so because they are the priority target of checks for suspicion of fraud as those who have the greatest interest in leaving French territory over a long period (Math, 2012). As we can see, whether or not there is an attachment to the country of immigration, returning to the country of origin proves difficult in practice due to the abovementioned lack of guarantee that their needs will be taken care of.

In Marseilles, the central district of Belsunce is a case in point: a place that can be described both as a transit area (Temime, 1995) and as a settling area for the chibanis who commute between both shores of the Mediterranean. Algeria is quite close, a mere boat trip away for some of them, who board "with a mere plastic bag as luggage for the journey", said the leader of a neighbourhood association. The living conditions of these workers, now retired, are precarious, even scandalous. In the heart of the district, in an association dedicated to these elderly people, about fifty men over 60 years of age are welcomed every morning for a free breakfast. Afterwards, they are offered access to health and legal services. Many of them live in the city centre of Marseille in hotels, digs and other unfit accommodation reminiscent of what they found on arriving in France back in the 1950s. Their health is also precarious. Many have diabetes, high blood pressure, not to mention bodies worn out by work. They have worked all their lives, sometimes undeclared by their employers, which means that they now draw meagre pensions. Reconstructing their careers in order to be able to access their dues is one of the arduous tasks of the social workers in the organisation that we met. A significant portion of their meagre pension is sent over to their families in Algeria. Some have lived and worked in other French cities and then chose to live in Marseille once they retired. This is not only because of the climate, but also because of more affordable rents and a lower cost of living than elsewhere - in the Belsunce district you can get a full meal for three euros.

The comparison between the Belsunce district in Marseilles and the Minguettes district in Vénissieux (located in greater Lyons) highlights life trajectories that are confronted with (in)hospitality in different ways. In both cases, people have experienced precarious housing. For the people living in Les Minguettes, access to social housing, although compulsory under public policies, has been experienced as beneficial, one's flat and one's neighbourhood now both being considered "home" after so many years. Mrs A., now 75 years old, arrived from Algeria in 1955 at the age of 12. When the Algerian war had just begun, her family sent her to France to join her brothers and sisters-in-law who had settled in Lyons. She got married in 1959 at the age of 16 . The couple then settled in digs in the centre of Lyons. Next, they moved on to the Chaâba shantytown, also known as Bidonville du boulevard de ceinture (literally, "the ring road shantytown") in Villeurbanne. Several years later, they were offered a flat in the Cité Olivier de Serres, built in the 1950s for repatriates of the Algerian war, Mrs A. explained to me:

And then we had good life there. We had a flat. It was the first time we saw a bathroom. Hot water, radiators and everything. When we moved in we bought our first TV with buttons. I put my children on a mattress on the floor and they slept like kings! We stayed there for quite a long time.

Then, seeing that the building was beginning to deteriorate, they asked to move out: 
We were offered a choice of La Duchère, Vaulx-en-Velin or Vénissieux

(Vénissieux, June 2018).

All of these were large-scale housing developments built on the outskirts of major cities in the late 1960s.

Mrs L., 80 years old, from Sétif in Algeria, spoke with her daughters about the "luxury" of gaining access to housing in the ZUP des Minguettes: First we lived in Villeurbanne, we were the "gones" of Chaâba", if you've read the book? That was us! Then they moved to Les Minguettes in 1968: It was America! they told me, referring to the size of the flats, and especially the fact that they had several bedrooms, a bathroom and toilets (Vénissieux, June 2013) (Leblanc, 2014, p. 82).

11 All the women we interviewed are still living in Les Minguettes, some of them since the construction of the ZUP in 1969 and some of them still in the same flat. This was where they raised their - often numerous - children in social housing ranging from T3s (3room flats) to T5s (5-room flats). Today, often widowed and living alone, they are under pressure from social housing providers who insist they should accept smaller flats. Such is the case of Mrs M., who came from Oran at the age of 15 and is now 81 years old. She has been a widow for four years and has six children, most of whom live far away. When we first met, she explained to me that following a "redevelopment" of the neighbourhood, their tower block had been knocked down and she and her husband had had to put up a fight to get at least a three-room apartment to be able to receive their children: Sometimes my daughters come home, what good is an F2?! A bedroom, a living room... What good is that? she said to me, shrugging her shoulders (Vénissieux, June 2013). Today, she still lives alone in her three-room flat. Even though, with no lift available in the building, she finds it harder and harder to climb the stairs, Mrs M. does not dare to ask for a change for fear of being forced to move to a two-room flat (Ibidem, p. 12).

12 In the centre of Marseilles, housing is still glaringly dilapidated. Some elderly people looked after by the Belsunce district association are now living in hotels following the collapse of their building. Accommodation is often reduced to single rooms, sometimes windowless and without a lift. On the Cours Belsunce, the café terraces become, even for elderly women, veritable "extensions of living space" (Ait Ben Lmadani, 2007, p. 232) to escape their four walls and loneliness.

\section{Risk of loneliness, families under pressure}

Conventional wisdom has it that there is a "North-South" dichotomy with regard to representations and treatment of old age, Northern countries being supposedly part of an individualistic culture as opposed to Southern countries, which are considered to be family friendly (Attias-Donfut, Gallou, 2006). While "with regard to older people, no culture has a monopoly on tenderness and no one ignores their family" (Samaoli, 2007, p. 103), the ethnographic data collected reveals the prevalence of the sometimes injunctive model of filial piety to be the norm (Attias-Donfut, Gallou, 2006, p. 154). In practice, women, who are more often than not widowed because of the age gap when they married and the often physically exhausting occupations of their husbands, live alone in their homes with nursing and/or household help if necessary. While in Les Minguettes, children - especially daughters - often live near their parents, in Marseilles 
many of the elderly men we interviewed have their families in Algeria. The women, on the other hand, have different backgrounds from those predicted by the homogenising pattern of family reunification. Some emigrated alone, are divorced, have no children or are experiencing family break-up. Consequently, for them, their difficulties with the French language, especially the written language, the complexity of administrative procedures which have to be carried out, largely online nowadays, ignorance of rights and the institutional and associative fabric, as well as mobility issues, lead to a significant risk of social isolation.

Another phenomenon that somewhat undermines a family friendly representation attributed to these women is what $\mathrm{C}$. Roth calls "the inversion of the intergenerational contract" (Roth, 2010). She notes that in Burkina Faso, impoverishment, rising youth unemployment and changes in lifestyles, including urbanisation, are causing older people to help the young rather than the other way round. In France, this situation is found among the women we interviewed, who are now elderly and often widowed and still provide for their adult children. Faced with this "vicious circle of impoverishment" (Ibid.), filial piety is undermined and very often takes second place. Among the women we met at Les Minguettes, many still house their daughters or sons who are either unemployed or make too little money from their jobs. They very often continue to provide for their children even though they have become adults. Similarly, several of them look after their grandchildren to help their working daughters. This reversal partly explains the impoverishment of the elderly, especially women who sometimes receive only a survivor's pension. This phenomenon can be observed for these women as well as for the general population on both sides of the Mediterranean.

\section{Both here and over there: players in the hospitality field are gearing up}

\section{The emergence of the associative fabric in France}

Faced with the vulnerable position of many elderly immigrants in France, in terms of social isolation or living conditions, institutions are struggling to address the issue. These people, especially when they do not have family carers, have little access to social rights. Moreover, as far as sociability is concerned, they often do not turn to places dedicated to the elderly. There are several reasons for this: the low appeal of the concept of leisure or at least the leisure activities offered by these spaces (oldfashioned dances, playing cards, etc.) and the cost of these structures are deterrents for the people we interviewed. Other spaces for socialising are thus preferred: places of worship, cafés (especially for men), associations dedicated to families such as social centres or those specialising in the reception of elderly immigrants such as social cafés or organisations dedicated to access to rights.

In Les Minguettes, at the social centres, one of the activities developed for adults are sociolinguistic workshops enabling non-French speakers to improve their command of the language in their daily life and social interactions. There was a significant presence of immigrant women over the age of 60 in these workshops when they were set up in the 1990s. Today, the successive migratory waves and, above all, the fact that these workshops have been redirected towards integration through employment have forced out the elderly public who have become a minority. Nevertheless, the women 
interviewed, as well as the volunteers and employees of the community centres, agree on the benefits in terms of sociability and learning for older people. Those who have been married and whose spouses used to take care of all the tasks outside the home (shopping and administrative procedures in particular), are faced, at the time of their spouse's illness and death, with significant language difficulties, especially when it comes to written French. When I met her, Mrs M. was 81 years old. She had been a widow for four years, living alone in her flat in Les Minguettes. She has six children, most of whom live far away. In the past 12 months she had been taking French classes at the social centre. She explained to me that she didn't go to school in Algeria but that she learned to speak French by playing with neighbours her own age. Even though she arrived in France at the age of fifteen, she told me with a smile that her language skills had gone downhill ever since. She does speak French fluently, but now that she is a widow and living alone, her specific wish is to be able to read notices in shops as well as the letters she receives, especially the bills. She explained to me that she had wanted to do this for a long time but had never found a place for people who mastered oral expression and only wanted to learn to read: "I am told that I need my grandchildren to help me but... I don't have the grandchildren with me" (Vénissieux, June 2013). Today, particularly following on from the research which has been carried out, a working group has been set up within the institution to address the specific needs of this population, particularly in terms of language and social isolation.

For other women we met at Les Minguettes, a religious association called a "mosque" by the inhabitants of the neighbourhood is another place of hospitality and sociability. The majority of the women in the mosque are elderly women. Some of them meet there every afternoon. With the help of women volunteers, they learn to read Koranic Arabic and also literary Arabic. Some of them clearly emphasise the social link, like a woman who told me "I want to come out of my bubble" or Mrs 0 . who explained her visit to the mosque thus:

"We went to the community centre, to do activities and all that, with the children and everything. And then when you retire, you have nothing to do but go round in circles, so I came here" (Vénissieux, May 2014) (Leblanc, 2014, p. 104).

In the context of immigration societies, where Islam is a minority,

"Above all, the mosque fulfils a social function which reveals the sometimes very strong links that can develop, in a situation of migration or post-migration, between people who do not belong to the same family but frequent the same mosque. This aspect emphasises the symbolic importance of the mosque as a place of socialising and solidarity" (Torrekens, 2009).

Moreover, in an associative and socio-educational logic, but also in order to protect the Muslim community in France, mosques are increasingly opening up to groups who are considered fragile, such as children and women, particularly elderly women.

In Marseilles, in the Belsunce district, an association created a space in 2008 dedicated to welcoming the district's elderly people. This project was created by activists appalled by the precariousness and discrimination that chibanis have been, and still are, subjected to in France. The only criterion for access to the programme is to be at least 60 years old. The high proportion of immigrants from Maghreb and sub-Saharan Africa in Belsunce, as well as access to professionals who speak Arabic and Wolof in the organisation, means that a majority of those attending the centre are chibanis and chibanias . Over the years, the association has thus built up expertise in the specific support of these people, in terms of rights (the six compulsory months a year in France 
and careers that are difficult to validate), of interpreting, but also in terms of sociological knowledge of this population. Although the vast majority are men, women have been knocking on the association's door for several years. Most of them arrived in France between the 1950s and the 1970s, but others have only recently arrived to look after a sick spouse who cannot return to his country of origin for the abovementioned reasons. On arrival, the situation of these women is thus very complex: in addition to disappointment with the precarious living conditions of their spouses, with whom they sometimes had little daily living experience, there is also a total lack of knowledge of French law, of the institutional and associative fabric, and also sometimes of the language. In addition to this, there are the children and family they have had to leave behind in their country of origin (Gallou, 2016). The association thus becomes both a shelter and an essential resource for them. Time slots and activities dedicated solely to women have been created by the association to allow them to access a safe space where they feel welcomed, listened to and acknowledged in their difficulties.

\section{Community relay in the country of origin}

The Moroccan example shows that the region of origin can also become a source of assistance, a community relay in the social and institutional problems experienced by these old age pensioners. A pre-existing social and associative fabric is sometimes used, at their level, to provide solutions for their isolation and administrative problems.

Thus, we were able to meet two Moroccan associations located in Agadir which, in two different ways, try to solve the problems of a population sometimes lost in "red tape" and in their rights and non-rights. One is made up of retired people who have worked in Europe, mainly in France, but also in Belgium, Germany or the Netherlands. It was set up in the early 2000 s by returning emigrants who realised that some of them had difficulty asserting their rights in the face of administrative problems and misunderstandings. Thus, the association's mission is to provide guidance and advice to those old age pensioners who have returned to their country of origin, or who are still living in Europe, for their administrative procedures, whether they concern the host country or Morocco. Several of its members who have returned to Morocco have described "unfair" situations in which did not have the same rights as if they had stayed in France. Some, still living in France, suggested that return was not really an option in view of the social consequences it could have: having their old-age benefits suspended and their medical expenses not reimbursed.

The second association we met claims to be militant. Led by a Franco-Moroccan, the son of an immigrant worker in France, the association is a strong advocate for the rights of immigrant workers and especially for the possibility of returning to their home country while retaining all social benefits, which are not exportable today. The association, which has little visibility on the ground for retired people, mainly lobbies French or Moroccan politicians in "a political struggle". It contributed to a bill that was tabled in $2017^{7}$ in France, but which failed due to lack of political support. The president of the association, who is familiar with the situation of these chibanis on a daily basis, did not pull his punches: we "let our old migrants die in France in outrageous conditions, without worrying about their rights", he said. (Agadir, October 2017). 
Support among migrant old age pensioners is also to be found outside the associations. In the region of Tiznit, for example, many retired people who have worked in France know each other and meet up on a daily basis in local cafés. These cafés, as places of male sociability, enable them to meet people who have had similar migratory experiences and who have lived in the same host societies. It was in one of these cafés that we met several of them. They were either back or still living in France and travel back and forth at least once a year. They explained that one of their main pleasures when they are in Morocco is to meet up with friends from France, Morocco and elsewhere to have tea or coffee, so that they do not get locked into a form of isolation. Far from making up a formal discussion or support group, these meetings allow for daily exchanges, advice and follow-up of each other's problems. Thus, discussions often revolve around daily "routine", but also around more technical questions, Mohamed, for example, did not understand to whom he was supposed to send the "life certificate" requested by the pension fund, and Abdelkbire wanted to know whether he could claim reimbursement for the medicine he bought the day before.

Moral as well as technical support, as well as social networks, e.g. the associative network, make up for the lack of information, misinformation and mistakes, but above all, they make it possible to "create a community" for a population that often feels marginalised.

\section{In conclusion}

The situations and initiatives discussed in our paper back up our claim that, faced with a global context that we consider inhospitable for these retired immigrants, a "hospitality counter-policy" is being implemented at local level by actors concerned in one way or another with migration issues on both sides of the Mediterranean. However, these actors, when they are associative, do depend on national and/or European policies, if only through subsidies, thus making them tenuous. The uncertainty of funding is exacerbated by the fact that many chibanis and chibanias do not hold French passports and therefore, despite having settled permanently in France, remain deprived of voting rights. This reinforces their social and political invisibility and inaudibility. Other actors, artists in this case, are mobilising around these issues through movies, such as the recently deceased director Rachid Oujdi, with his film Perdus entre deux rives, les Chibanis oubliés ("Lost between two shores, the forgotten Chibanis) (Oujdi, 2014) or Nadir Dendoune director of the documentary film Des figues en avril ("Figs in April") paying tribute to his mother (Dendoune, 2018).

The chibanis and chibanias themselves are rallying on both sides of the Mediterranean to assert their rights. For example, this was the case in 2010 in Toulouse with the support of an association called "Justice and Dignity for the Chibanis". The members of the association occupied the premises of Carsat (a French institution that manages retirement pensions) to protest against its discriminatory controls (Host, Pépin, 2012). More recently, in 2018, the victory of the Moroccan railway workers or, where applicable, their widows, over the SNCF, made it possible to have forty years of wage discrimination acknowledged and compensated. ${ }^{8}$ Although often described as belonging to an age that demanded they remain "invisible" and "humble" (Bouamama in Guénif-Souilamas, 2006, p. 197), these now elderly immigrants (and their children) have always fought for their rights. It would therefore be a mistake to view them only 
as victims. As Fatima Ait Ben Lmadani points out, the "image of the 'wise' elderly person, respected because they pray and wait 'calmly' for death, appears far from the reality" (Ait ben Lmadani, 2007, p. 337). In fact, many of the Moroccan immigrant women she met, as well as the women and men she met in the course of our respective field surveys, continue to work, to live on their own and to take steps to gain "social recognition", whether from French institutions, their peers, their emigration societies or their families.

In the face of the long-term inhospitality that we have observed and described in this paper, hospitality and mutual aid initiatives are being set up. However, they are mainly implemented by associations and citizens' groups, which compensate for the shortcomings of the state. There has been progress in the recognition of the rights and needs of Chibanis and Chibanias, but there is still a lot to be done and unfortunately ageing is also taking its toll.

\section{BIBLIOGRAPHY}

Agier, Michel (2011) L'encampement du monde, Plein droit, vol. 90, n 3, pp. 21-24.

Ait Ben Lmadani, Fatima (2007) La vieillesse illégitime? Migrantes marocaines en quête de reconnaissance sociale, Paris, Université Paris-Diderot, 371 p. PhD Thesis in Sociology: University Paris Diderot, URMIS: 2007.

Ait Ben Lmadani, Fatima (2012) Femmes et émigration marocaine. Entre invisibilisation et survisibilisation: pour une approche postcoloniale, Hommes \& Migrations, No. 1300, pp. 96-103. Attias-Donfut, Claudine; Gallou, Rémi (2006) L'enracinement. Enquête sur le vieillissement des immigrés en France, Paris, Armand Colin, 292 p.

Arab, Chadia (2013) Le troisième âge : le « migrant inutile », Hommes \& Migrations, $\mathrm{n}^{\circ}$ 1303, pp. 47-55.

Brugère, Fabienne; Le Blanc, Guillaume (2017) La fin de l'hospitalité. Lampedusa, Lesbos, Calais... Jusqu'où irons-nous ? Paris, Flammarion, $240 \mathrm{p}$.

Chavanon, Olivier; Leblanc, Guillaume (2018) Immigration et habitat de fortune, une sempiternelle redécouverte. Écarts d'identité, n 130, pp. 8-11.

Daum, Christophe (2007) Migration, retour, non-retour et changement social dans le pays d'origine, In Petit, V. (Ed.) Migrations internationales de retour et pays d'origine. Paris, CEPED, pp. 157-169 (Rencontres).

Dendoune, Nadir (2018) Des figues en avril. Documentary film, 58 minutes.

El Hariri, Saâdia (2003) Les femmes et le retour au pays d'origine, Hommes \& Migrations, $\mathrm{n}^{\circ} 1242$, pp. 43-52.

Gallou, Rémi (2016) Vieillir sans conjoint mais vieillir entourées : un défi pour les femmes immigrées, Gérontologie et Société, vol. 38, n 149, pp. 105-123. 
Guénif-Souilamas, Nacira, (dir.) (2006) La république mise à nu par son immigration, Paris, La Fabrique, $151 \mathrm{p}$.

Host, Jérôme; Pépin, Juliette (2012) Justice et dignité pour les chibanis, Plein droit, n 93, pp. 8-11.

Math, Antoine (2012) Le contrôle par la résidence, Plein Droit, nº 93, pp. 3-7.

Leblanc, Julie (2014) « Une diversité [in]visible? » Des femmes immigrées âgées dans la Cité, Lyon, Université Lumière - Lyon 2. Mém. Master II: Anthropology: Université Lumière Lyon 2: 2014.

Moujoud, Nasima (2010) Genre et Migration. Entre androcentrisme et prisme de la 'culture d'origine', Naqd, Revue d'études et de critique sociale, $\mathrm{n}^{\circ} 28$, pp. 55-75.

Oujdi, Rachid (2014) Perdus entre deux rives, les Chibanis oubliés. Documentary film, $52 \mathrm{mn}$.

Paiva, Michelle (2012) Des femmes invisibles, Plein Droit, $n^{\circ}$ 93, pp. 21-24.

Petit, Véronique (Ed.) (2007) Migrations internationales de retour et pays d'origine. Paris, CEPED, 208

p. (Rencontres).

Roth, C (2010) Les relations intergénérationnelles sous pression au Burkina Faso, Autrepart, $\mathrm{n}^{\circ} 53$ pp. 95-110.

Samaoli, Omar (2007) Retraite et vieillesse des immigrés en France. Paris, L'Harmattan, 276 p.

Sayad, Abdelmalek (1999) La double absence. Des illusions de l'émigré aux souffrances de l'immigré. Paris, Le Seuil, $437 \mathrm{p}$.

Sayad, Abdelmalek (2001) La vacance comme pathologie de la condition d'immigré. Le cas de la retraite et de la pré-retraite. Revue Européenne des Migrations Internationales, vol. 17, n 1, pp. 11-36.

Schaeffer, Fanny (2001) Mythe du retour et réalité de l'entre-deux. La retraite en France, ou au Maroc, Revue Européenne des Migrations Internationales, vol. 17, n 1, pp. 165-176.

Temime, Emile (1995) Marseille transit: Les passagers de Belsunce. Paris, Autrement, 139 p. (Série Monde - Français d'ailleurs, peuple d'ici).

Torrekens, Corinne (2009) L'espace de la mosquée à Bruxelles : nouveaux liens sociaux et investissement politique, Revue des mondes musulmans et de la Méditerranée, n 125, pp. 23-45.

\section{NOTES}

1. Julie Leblanc's ethnographic survey started out in 2013 and is based on interviews with 48 women aged between 59 and 83, mainly from Algeria but also from Tunisia, Morocco and West Africa. The data was collected in the urban area of Les Minguettes in Vénissieux (Rhône) through participant observation in an association of female residents and in the social centres of the neighbourhood as a volunteer in French classes, but also as a learner of Arabic in a mosque in Les Minguettes. Life story interviews were collected from these women in these structures but also in the homes of several of them. In addition, in 2018, ten research workshops shared with an artist and a photographer were conducted with 14 of these women and resulted in an exhibition and a film retracing the memory and experiences of these women in the neighbourhood. In Marseilles, in 2019, the field work was carried out with the help of an association for access to rights for retired people in the Belsunce neighbourhood. Once again, ten shared research workshops were conducted as well as life-story interviews with 17 women and in partnership with a sound documentarist to retrace the lives of these women and their vision of the neighbourhood. A day of meetings between the women of Les Minguettes and Belsunce was organised in June 2019. 
2. Jordan Pinel's field survey took place between 2017 and 2019 in the Souss-Massa region (Morocco) and was centred around a biographical approach with matrices that included the residential and family aspects of mobility, which constituted the core of the survey. A semidirective interview followed the grid in order to provide nuances and clarifications to better understand the interactions and interferences between the biographical events of the individuals and those of their relatives. The sample consisted of 20 Moroccans and Franco-Moroccans (all born in Morocco and having acquired French nationality): 18 men and 2 women. In addition, a dozen additional interviews were conducted with institutional, associative and private actors "gravitating" around the presence of these retired people: representatives of Moroccan foundations or ministries focused on the issue of Moroccans Residing Abroad, two associations of Moroccans emigrating abroad or retired, the CNSS (National Social Security Fund) of Tiznit.

3. Issue No. 93 of the journal Plein Droit, «Vieillesse immigrée, vieillesse harcelée » reports on those restrictions.

4. For the sake of anonymity, the names of the associations referred to in this paper will not be identified.

5. ${ }^{5}$ 130,000 dirhams are worth about 12,000 euros.

6. In reference to Azouz Begag's book published in 1986, under the title Les gones du Chaâba, which recounts his childhood in this Villeurbanne shantytown. "gone" in the local dialect means "kid".

7. Bill No. 4412 introduced in the French National Assembly on 25 January 2017 and "aimed at improving the living conditions of Chibanis and their families".

8. On this subject, see the article in Le Monde, 17 April 2018, "Les chibanis discriminés l'emportent définitivement face à la Sncf». Source: https://www.lemonde.fr/police-justice/ article/2018/04/27/les-chibanis-discrimines-l-emportent-definitivement-face-a-la-

sncf_5291683_1653578.html (last access 17 May 2019).

\section{ABSTRACTS}

In this paper, we discuss the concept of (in)hospitality and its implications in the daily life of elderly immigrants in France today. On the basis of the qualitative surveys we used, we have come to focus more specifically on the ageing of chibanis and chibanias, those immigrants who came to France mostly under state migration programmes from the 1960s onwards. Some of them face unsafe and precarious living conditions and severe cuts in their social rights, thereby epitomizing the inhospitable practices of institutions. In light of this, we argue that it is the local actors of hospitality, often associations, who have to take over and try to redress situations that are perceived as unfair. The people concerned also participate in (re)creating spaces for hospitality and mutual aid in places such as cafés, but also in conquering and asserting their rights and the social recognition they lack. These actors of civil society are mobilised "here" and "there", i.e. both in the host country and in the country of origin - Morocco in this case study -, which is somehow reminiscent of the "in-between" life for part of these now ageing populations.

\section{INDEX}

Keywords: associations, elderly people, access to care, reception, daily life, Chibanis Geographical index: Algerie, France, Maroc 


\section{AUTHORS}

\section{JULIE LEBLANC}

PhD student in Anthropology, LADEC (Fre 2002) Université Lumière Lyon 2, Fellow IC Migration $(2018$ - 2021)

julie.leblanc@univ-lyon2.fr

JORDAN PINEL

PhD student in Geography, MIGRINTER Laboratory (UMR 7301) CNRS / University of Poitiers jordan.pinel@univ-poitiers.fr 